\author{
Budo Zindovic \\ Teaching Assistant \\ University of Belgrade \\ Faculty of Civil Engineering \\ Ljubodrag Savic \\ Professor \\ University of Belgrade \\ Faculty of Civil Engineering \\ Radomir Kapor \\ Assistant Professor \\ University of Belgrade \\ Faculty of Civile Engineering \\ Nikola Mladenovic \\ Professor \\ University of Belgrade \\ Faculty of Mechanical Engineering
}

\section{Stepped Spillway Flow - Comparison of Numerical And Scale Models}

This paper deals with flow modelling of the stepped spillway for the Bogovina dam. The analysis was conducted using three approaches: scalemodelling, empirical equations and numerical modelling. An acceptable agreement was achieved between the empirical equations and the numerical model results, while both of them exhibit considerable differences when compared to scale-model. These discrepancies can be contributed to the difficulties in modelling the process of air-entrainment. Since air-entrainment is important for providing good estimates, existing empirical equations as well as numerical models require further improvements.

Keywords: RCC dam, stepped spillway, scale model, numerical model, Bogovina dam.

\section{INTRODUCTION}

In the last three decades, stepped spillways have become common overflow structures for rollercompacted concrete (RCC) dams. The steps have significant influence on the energy dissipation along the spillway and reduce the size and the cost of the stilling basin. The application of new construction technique of roller-compacted concrete, had lowered the construction cost even more. Low cost, combined with good energy dissipation make RCC dams a superior alternative to traditional concrete gravity dams with smooth spillways.

Hydraulic characteristics of stepped spillways can be assessed in various ways: by using the empirical equations (during the preliminary design process), scale modelling, and numerical modelling (in the final design process). These three approaches are applied to the spillway of the 'Bogovina' dam.

RCC dam 'Bogovina' is planned to impound the water of the Timok River. Proposed height of the dam is $54 \mathrm{~m}$, with crest width of $396 \mathrm{~m}$. The design flow of the spillway is $Q_{0,01 \%}=372 \mathrm{~m}^{3} / \mathrm{s}$ and the width is $115 \mathrm{~m}$. The slope angle of the spillway is $\phi=51,34^{\circ}$. Proposed height of the first four steps is $45 \mathrm{~cm}$, while the remaining 45 steps are to be $90 \mathrm{~cm}$ high. The downstream end of the spillway is connected to the stilling basin.

\section{MATERIALS AND METHODS}

\subsection{Scale model}

In order to obtain valid data for the analyses, the scale of the model should be chosen so that the flow can exhibit adequate air entrainment $[3,4,5,7,16]$. To comply with this requirement, it is sufficient to use

Received: August 2013, Accepted: December 2013 Correspondence to: Budo Zindovic

Faculty of Civil Engineering,

Bulear kralja Aleksandra 73, 11120 Belgrade, Serbia

E-mail: bzindovic@hikom.grf.bg.ac.rs

doi:10.5937/fmet1403218Z

(C) Faculty of Mechanical Engineering, Belgrade. All rights reserved scales between $1: 10$ to $1: 12$. Since the large spillway discharge of the Bogovina dam, and importance of correct air entrainment modelling for representative energy dissipation, it was chosen to build only a section of the weir with stepped spillway (Figure 1) [14, 20]. Scale of such model was 1:12 with respect to Froude similitude. Width of this model was $60 \mathrm{~cm}$. Water levels in the spillway were measured with point gauges.

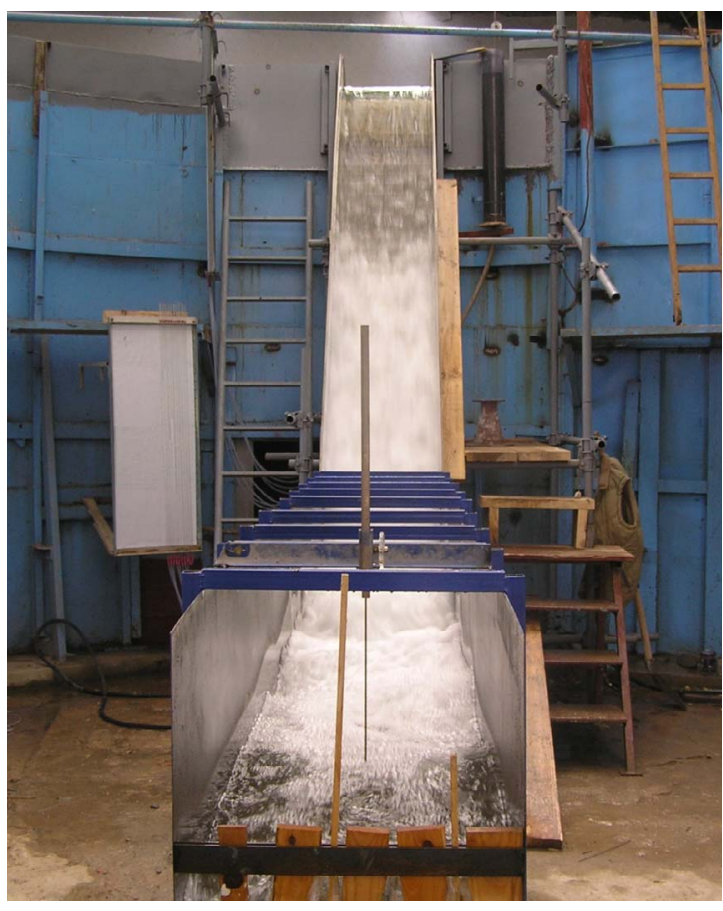

Figure 1. Scale model of the section of the weir with the stepped spillway of the Bogovina dam [14, 20]

\subsection{Empirical equations for the stepped spillways}

Boes and Hager [4, 5] conducted a series of tests on scale models, and devised equations for the analysis of the stepped spillways flow. In the remaining part of this section, an overview of this analysis is presented. The details are outlined in the literature [14]. The most important variables used in this study, are outlined in Figure 2. 


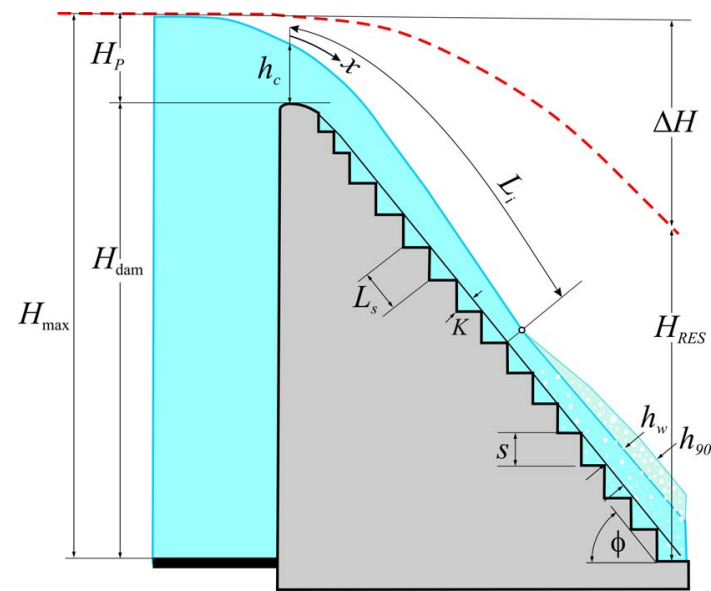

Figure 2. Cross-section of the typical stepped spillway dam with quantities used in the empirical equations [14]

Inception point. Inception point is the location where boundary layer intersects the free surface downstream of the weir. Downstream of this location a significant air entrainment occurs. The position of the interception point can be assessed from:

$$
L_{i}=\frac{5,90 h_{c}^{6 / 5}}{(\sin \phi)^{7 / 5} s^{1 / 5}},
$$

where $L_{i}$ - distance from weir crest to inception point, $h_{c}-$ critical depth, $\phi-$ slope of the spillway, $s-$ step height.

Uniform flow characteristics. If the spillway chute is long enough, the flow is expected to attain uniform conditions. Since this type of flow is positioned downstream of the inception point, it will exhibit a significant air entrainment. One can distinguish between the clear-water depth $h_{w, u}$, and the mixture depth, $h_{90, u}$ where the concentration of entrained air is $90 \%$ :

$$
\begin{gathered}
h_{w, u}=0.215 F_{*}^{2 / 3} s, \\
h_{90, u}=0.5 s F_{*}^{(0,1 \tan \varphi+0,5)} .
\end{gathered}
$$

New variable, $F_{*}$, is the Froude number with step height as characteristic length:

$$
F_{*}=\frac{q_{w}}{\sqrt{g \sin \phi s^{3}}},
$$

and $q_{w}$ is the flow rate of water per unit width of the spillway. Depth-averaged air concentration for uniform flow can be assessed as:

$$
C_{u}=1-\frac{h_{w, u}}{h_{90, u}} .
$$

Residual energy along the spillway chute. Residual energy per unit weight of the water is an important parameter for designing the stilling basin. The most important problem is the cavitation since the flow field corresponds to a water jet with moderate impact angle [12, 13]. As the cost of the basin can be significant, it is essential to provide a reasonably good estimate of the residual energy at the downstream end of the spillway. To assess residual energy along the spillway, it is required to compute the friction factor along the spillway. By choosing the step height as the reference length, Boes and Hager $[4,5]$ proposed the equations (6) and (7). The average of the two values, obtained from these equations, can used as representative friction factor $f_{b}$.

$$
\begin{gathered}
f_{b}^{\prime}=[0.5-0.42 \sin (2 \varphi)]\left(\frac{s \cos (\phi)}{4 h_{h, w}}\right)^{0,2}, \\
f_{b}^{\prime \prime}=\frac{0.5-0.42 \sin (2 \phi)}{\left[1.0-0.25 \log \left(\frac{s \cos (\phi)}{4 h_{h, w}}\right)\right]^{2}},
\end{gathered}
$$

Maximum head-water elevation, $H_{\max }$, is related to the dam height and the critical depth:

$$
H_{\text {max }}=H_{d a m}+1.5 h_{c},
$$

Residual energy head at the downstream end of the spillway is computed in two ways, depending whether the uniform flow condition were attained or not. If uniform flow conditions are attained, i.e. $H_{\text {dam }} / h_{c} \geq 15 \div 20$, the following equation applies:

$$
H_{R E S}=\frac{F H_{\max }}{\frac{H_{d a m}}{h_{c}}+F},
$$

where parameter $F$ is computed using the formula:

$$
F=\left(\frac{f_{b}}{8 \sin \varphi}\right)^{1 / 3} \cos \varphi+\frac{\kappa}{2}\left(\frac{f_{b}}{8 \sin \varphi}\right)^{-2 / 3}
$$

Parameter $\kappa$ in (10) takes into account the nonuniform velocity distribution along the vertical and the value of 1,1 is chosen.

If uniform flow conditions were not attained $\left(H_{\text {dam }} / h_{c} \leq 15 \div 20\right)$, the following expression is used:

$$
H_{R E S}=H_{\text {max }} \mathrm{e}^{\left(-0.045\left(\frac{K}{D_{h, w}}\right)^{0,1}(\sin \varphi)^{-0,8}\right) \frac{H_{d \text { dem }}}{h_{c}}} .
$$

Residual energy distribution along the spillway can be assessed from equations (6) - (10) by substituting the dam height with the elevation difference between weir crest and current step.

\subsection{Numerical modelling of the flow along the spillway}

The popularity of computer simulations in the field of fluid mechanics increased in the last three decades. The availability of more and more powerful computers at low price will increase the use on numerical models and will introduce them as standard tool in the design process.

Due to strong air-water mixing, the flows is regarded as multiphase. 
Air-water flow can be modelled in two ways: by forming the equations for the mixture or for every component separately. Pro of the first approach is its intrinsic simplicity (compared to the second) but is bound to cases with low air concentrations. Second approach is preferred in cases where turbulent motions have significant influence on the mixing phenomenon. The process of dissolving of air in water is usually not modelled, as insignificant for the given problem.

Water and air were modelled as separate interpenetrating continua. Mass and momentum conservation equations are solved for each phase, $q$ $[2,6]$ :

$$
\begin{gathered}
\frac{\partial}{\partial t}\left(\alpha_{q} \rho_{q}\right)+\frac{\partial}{\partial x_{k}}\left(\alpha_{q} \rho_{q} u_{q}^{k}\right)=0 \\
\frac{\partial}{\partial t}\left(\alpha_{q} \rho_{q} u_{q}^{i}\right)+\frac{\partial}{\partial x_{j}}\left(\alpha_{q} \rho_{q} u_{q}^{j} u_{q}^{i}\right)=\alpha_{q} \rho_{q} g^{i}- \\
-\alpha_{q} \frac{\partial p}{\partial x_{i}}+\frac{\partial \tau_{q}^{i j}}{\partial x_{j}}+F_{q}^{i}
\end{gathered}
$$

where $\alpha_{q}$ - fraction (concentration) of the phase $q$ in the control volume, $\rho_{q}$ - density of the phase $q, u_{q}^{i}-$ velocity component of phase $q$ in the $x_{i}$ direction, $g^{i}-$ gravity acceleration vector, $p$ - pressure, $\tau_{q}^{i j}-$ shear stress tensor (viscous and turbulent) for the phase $q$, and $F_{q}^{i}$ - force term, accounting for the interaction between phases (lift, virtual mass). Vectors and tensors are written in tensor notation, and each component in the Cartesian direction $x_{i}$ is denoted by the upper index $(i=1,2,3)$. Phase $q$ is indicated by the lower index $(q=1,2$ for air and water, respectively). In order to solve the system of equations (1)-(2) for both phases, it is required to model the influence of fluctuations on the time-averaged quantities. Various approaches to this problem exists and the one used in this study is to model the transport of the correlation of velocity fluctuations (known in the literature as Reynolds' stress model) $[2,9,17]$ :

$$
\begin{aligned}
& \frac{\partial}{\partial t}\left(\alpha_{q} \rho_{q} R_{q}^{i j}\right)+\frac{\partial}{\partial x_{k}}\left(\alpha_{q} \rho_{q} u_{q}^{k} R_{q}^{i j}\right)= \\
& =D_{q}^{i j}+P_{q}^{i j}+\phi_{q}^{i j}+\varepsilon_{q}^{i j}
\end{aligned}
$$

where $R^{i j}$ is the "Reynolds stress tensor", $D^{i j}$ - diffusion tensor (molecular and turbulent), $P^{i j}$ - Reynolds stress production tensor, $\phi^{i j}$ - pressure-strain tensor, and $\varepsilon^{i j}$ the dissipation tensor. In the case of strong anisotropy of shear stresses, the presented model has the advantage over simpler models (with one and two transport equations for fluctuations) $[8,17]$.

The system (1) - (3) for both $(q)$ phases is solved by supplying appropriate boundary conditions. For (1), one must prescribe phase distribution while (2) requires the velocity distribution for all boundaries.

Exact solutions for the presented equations exist only for highly simplified cases. As these results are inconvenient for the design purpose, previous equations are solved approximately. The widely used methods are: finite differences, finite volume and finite element $[9,11,15,18]$. Due to its relative simplicity and high flexibility, the majority of the available numerical models (commercial, free and open-source) implement finite volume method $[1,2,9,19]$.

Computational mesh used in this study, is presented in the Figure 3. Initial mesh was refined in parts of the domain where steep velocity gradients were observed, in the vicinity of the free-surface (due to the air-water mixing) and in the triangular cavities (due to the strong velocity gradients and streamline curvature).

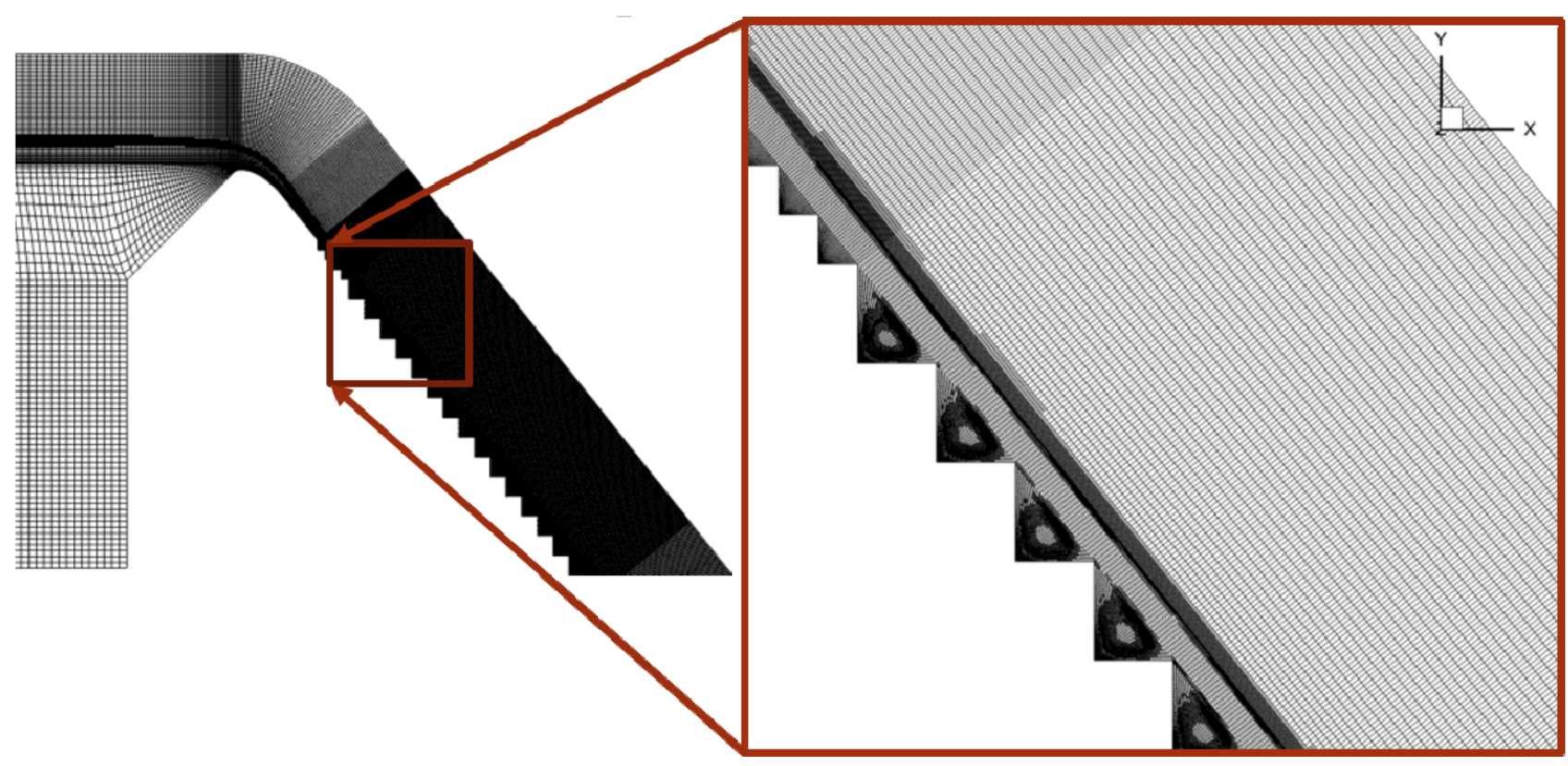

Figure 3. Computational mesh for the prototype stepped spillway. Initial mesh was refined in the areas of steep velocity gradients, intense air-water mixing near the free-surface as well as in the triangular cavities where rotational flow conditions were expected. Rough mesh was used upstream of the weir as the velocities were two to three orders of magnitude smaller than the ones along the spillway. 


\section{RESULTS AND DISCUSSION}

In this section, the results obtained from the scale model, empirical equations [14] and numerical model Ansys Fluent are compared for the design flow-rate of $Q=372 \mathrm{~m}^{3} / \mathrm{s}$. The results are summarized in Table 1 . The results obtained from the scale-model were upscaled to a prototype dam.

Table 1. Summary of the results from the scale-model, empirical equations and numerical model for the Bogovina dam stepped spillway. All values are up-scaled to the prototype dam: $L_{i}$ - inception point distance, $h_{90, u}$ - uniform flow mixture depth, $C_{u}$ - averaged air concentration for uniform flow, $\boldsymbol{h}_{\mathbf{9 0 , 1 1}}$ and $\boldsymbol{h}_{\mathbf{9 0 , 1 6}}$ - mixture depths at steps 11 and 16, $H_{R E S}$ - residual energy at step 16.

\begin{tabular}{|c|c|c|c|}
\hline & Scale-model & Empirical eqs. & Fluent \\
\hline$L_{i}[\mathrm{~m}]$ & 7,12 & 8,74 & 8,9 \\
\hline$h_{90, u}[\mathrm{~m}]$ & 0,72 & 0,55 & 0,52 \\
\hline$C_{u}[-]$ & - & 0,55 & 0,22 \\
\hline$h_{90,11}[\mathrm{~m}]$ & 0,56 & 0,61 & 0,51 \\
\hline$h_{90,16}[\mathrm{~m}]$ & 0,72 & 0,62 & 0,52 \\
\hline$H_{R E S}[\mathrm{~m}]$ & - & 8,12 & 4,4 \\
\hline
\end{tabular}

The inception point. As seen from Table 1, length from the weir crest to the inception point is the smallest for the scale-model. The location computed from empirical equations and numerical model are in good agreement with each other, and are somewhat larger than the measured.

Uniform flow mixture depths and air concentrations. The uniform flow mixture depths computed from empirical equations and numerical model show good agreement, but both of them are smaller than the measured. This could come from the fact that the uniform depth might not have been attained at the scale model.

As the concentration of the entrained air was not measured, comparison was made only between the results of the empirical equations and the numerical model. The difference between them is significant $(2.5$ times). The reason for this discrepancy can be attributed to the inability of the numerical model to adequately reproduce the process of air entrainment, especially in the zone of break-up of water stream into droplets. This problem is illustrated in Figure 4. The sharp drop for concentrations between 0.8 and 0.85 is a clear

a)

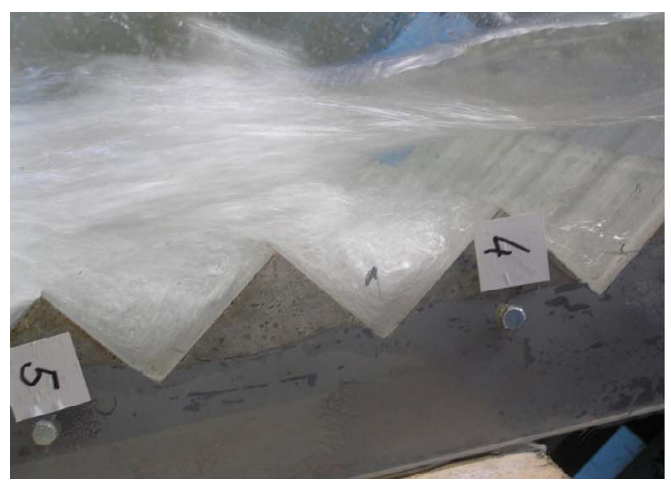

deficiency of present model and it requires further improvements. The problem of air-entrainment for water jets is the topic of recent studies [10] but there is still no adequate model for the spillway flow.

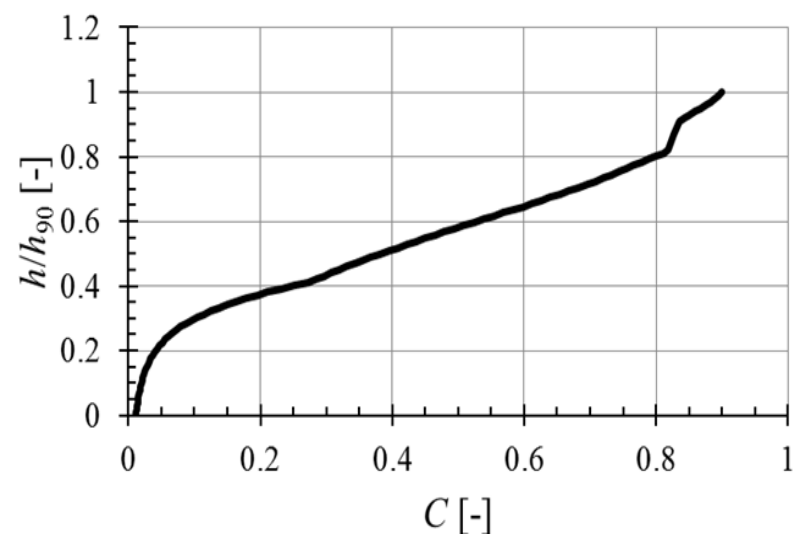

Figure 4. Simulated air concentration at the downstream end of the spillway. Sharp drop in the air concentration between 0.8 and 0.85 is the result of model inability to predict air-entrainment.

Mixture depths at the steps 11 and 16. The measured mixture depths and the depths obtained with the empirical equations are larger than the depths from the numerical model. The disagreements at the step 11 are within acceptable limits, which cannot be observed for the step 16. From the analysis presented in [14], the flow is expected to attain the uniform condition between the steps 11 and 16. As the depths obtained from the numerical model in the respective sections are similar, one can conclude that the uniform flow occurs further upstream than expected in the numerical model. Aside from the overall flow structure, it is important to consider the flow field within the triangular cavities formed by the steps. The numerical model flow field exhibits the swirls inside the cavity, which was also observed in the scale model (see Figure 5). This flow pattern is visualized by the streamlines in the numerical model and the entrained air in the scale model photo. Also, it is noted that the numerical model is able to reproduce air-water mixture only to a certain extent, in the region close to the free surface. However, the model isn't able to reproduce the air entraining in the cavity itself.

b)

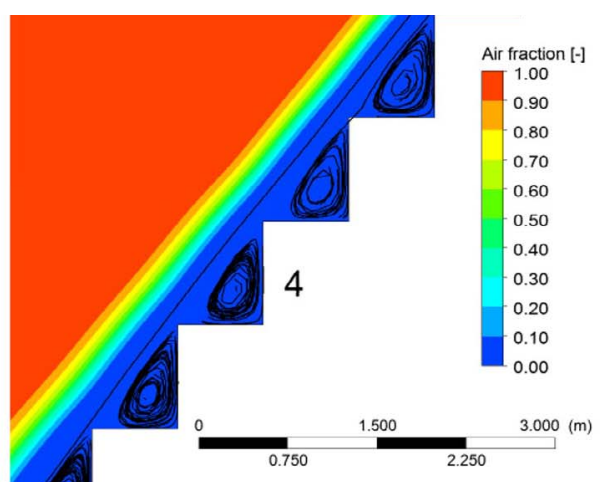

Figure 5. Air entrainment at the stepped spillway obtained by: a) scale-model, b) numerical model. The recirculating flow in the triangular cavity, formed by the steps, was observed on the scale model as well as the air entrained in the cavity. The numerical model was able to reproduce the recirculating flow pattern in the cavity (see the streamlines). Modelling of air water mixing was restricted to the free surface zone, but was not reproduced within the cavity itself. 
Residual energy head. Residual energy head (residual energy per unit weight of water) was analysed using the empirical equations and numerical model only. The residual energy head obtained from the numerical model is $\approx 50 \%$ of the value computed by the empirical equations. The reason for the difference could be the discrepancy of air concentration. As shown in $[4,5]$, the friction factor decreases with air concentration. As stated previously, the air concentrations from the numerical model are smaller than expected (empirical equations), which results in larger friction factor and larger energy dissipation. Since the reliable prediction of energy dissipation is of crucial importance for a stilling basin design, it is necessary to conduct further research in order to obtain an accurate prediction of the residual energy.

\section{CONCLUSIONS}

The comparison between the results of the scale-model, empirical equations, and numerical model Ansys Fluent for the Bogovina dam are presented. The following can be concluded:

- Location of the inception point is obtained with acceptable agreement for all three approaches.

- Uniform flow mixture depths by the numerical model are predicted upstream from the position expected by the empirical equations.

- Entrained air concentration for the uniform flow conditions is significantly underestimated by the numerical model.

- Although the flow field over the steppes is well reproduced, the numerical model failed to simulate the air entrainment process inside the triangular cavity formed by the steps.

- Residual energy is significantly underestimated by the numerical model, which is not on the safe side for stilling basin design.

- In order to provide good estimates for design purposes of the stepped spillways, the existing empirical equations and the numerical model require further improvements.

\section{ACKNOWLEDGEMENT}

Authors acknowledge the financial support through the projects TR37009, TR37010 and TR 35043, funded by the Serbian Ministry of Education, Science and Technological Development.

\section{REFERENCES}

[1] ANSYS $^{\circledR}$ Academic Research, Release 14.0, Help System, ANSYS CFX-Solver Theory Guide, ANSYS Inc., 2011.

[2] ANSYS $^{\circledR}$ Academic Research, Release 14.0, Help System, ANSYS Fluent Theory Guide, ANSYS, Inc., 2011.

[3] Boes, R.M.: Scale effects in modelling two-phase stepped spillway flow, in: Proceedings of the International Workshop on Hydraulics of Stepped
Spillways, 22-24.03.2000, Zürich, pp. 53 - 60, 2000.

[4] Boes, R.M., Hager, W.H.: Two-Phased Flow Characteristics of Stepped Spillways, Journal of Hydraulic Engineering, Vol. 129, No. 9, pp. 661-670, 2003.

[5] Boes, R.M., Hager, W.H.: Hydraulic Design of Stepped Spillways, Journal of Hydraulic Engineering, Vol. 129, No. 9, pp. 671-679, 2003.

[6] Brennen, C.E.: Fundamentals of Multiphase Flows, Cambridge University Press, 2005.

[7] Chanson, H.: Stepped spillways and chutes, Swets \& Zeitlinger B. V., Lisse, Netherlands, 2002.

[8] Davidson, P.A.: Turbulence - An Introduction for Scientists and Engineers, Oxford University Press, New York, 2005.

[9] Ferziger, J.H., Perić, M.: Computational Methods for Fluid Dynamics, $3^{\text {rd }}$ edition, Springer Verlag, Heidelberg, 2002.

[10] Guha, A., Barron, M.R., Balachandar, R.: Numerical simulation of high-speed turbulent water jets in air, Journal of Hydraulic Research, Vol. 48, No. 1, pp. 119-124, 2010.

[11] Hirsch, C.: Numerical Computation of Internal and External Flows, John Wiley \& Sons, Chichester, 1992.

[12] Hutli, F.A.E., Nedeljković, M.: Investigation of a Submerged Cavitating Jet Behaviour: Part One The Phenomenon, Detection Technique and SonoLuminesence, FME Transactions, Vol. 35, No. 3, pp. 113-119, 2007.

[13] Hutli, F.A.E., Nedeljković, M.: Investigation of a Submerged Cavitating Jet Behaviour: Part Two Influences of Operating Conditions, Geometrical Parameters and Arrangements of Detection System, FME Transactions, Vol. 35, No. 3, pp. 121-128, 2007.

[14] Kapor, R., Savić, Lj., Žugić, D., Petrović, N., Rula, M.: Comparison of computed and scale model results of stepped spillways, in: Proceedings of the $14^{\text {th }}$ Conference of Serbian Association of Hydraulic Research, 13-15.11.2006, Fruška Gora, pp. 105-117.

[15] LeVeque, R.J.: Finite Volume Methods for Hyperbolic Problems, Cambridge University Press, Cambridge, 2003.

[16] Minor, H.E., Boes, R.M.: Hydraulic design of stepped spillways, in: Proceedings of the $29^{\text {th }}$ IAHR Congress, 16-21.09.2001, Beijing, pp. 754 - 759.

[17] Pope, S.B.: Turbulent Flows, Cambridge University Press, 2000.

[18] Versteeg, H.K., Malalasekera, W.: An Introduction to Computational Fluid Dynamics - the Finite Volume Method, Pearson Education Limited, Harlow, 2007.

[19] Weller, H.G., Tabor, G., Jasak, H., Fureby, C.: A tensorial approach to computational continuum mechanics using object orientated techniques, 
Computers in Physics, Vol. 12, No. 6, pp. 620-631, 1998.

[20]Žugić, D., Kapor, R., Pop-Trajković, V., Petrović, N., Rula, M.: Scale modeling of stepped spillway in two different scales, in: Proceedings of the $14^{\text {th }}$ Conference of Serbian Association of Hydraulic Research, 13-15.11.2006, Fruška Gora, pp. 19-28.

\section{NOMENCLATURE}

$\underline{C} \quad$ air concentration [-]

$\underline{f_{b}} \quad$ friction coefficient for the spillway [-]

$\underline{h}_{902 \underline{u}} \quad$ uniform flow depth for $C=0.9$ [m]

$h_{w, 2} \quad$ clear-water depth for uniform flow

$\underline{h}_{\underline{w} 2 \underline{u}} \quad$ conditions $[\mathrm{m}]$

$\underline{h}_{c} \quad$ critical depth [m]

$\underline{H}_{\text {dam }} \quad$ dam height [m]

$\underline{H}_{\text {max }} \quad$ maximum head-water elevation

$H_{R E S} \quad$ residual energy head (energy per unit

$\underline{\text { RES }}$ weight of water) [m]

$\underline{L}_{i} \quad$ interception point distance [m]

$R_{i j} \quad$ Reynolds' or turbulent stress [Pa]

$R_{i j} \quad R_{i j}=-\rho \overline{u_{i} u_{j}}$

\section{Greek symbols}

$\alpha$

fraction of the phase in the control volume [-]

$\rho \quad$ phase density $\left[\mathrm{kg} / \mathrm{m}^{3}\right]$ $\tau_{i j} \quad$ Reynolds or turbulent stress $\tau_{i j}=-\rho \overline{u_{i} u_{j}}$

\section{Superscripts}

$i \quad$ index of the coordinate direction

$u \quad$ uniform flow conditions

$q \quad$ index of the phase (1 - air, 2 - water)

\section{СТРУЈАЊЕ У СТЕПЕНАСТОМ БРЗОТОКУ: ПОРЕБЕЊЕ РЕЗУЛТАТА ФИЗИЧКОГ И НУМЕРИЧКОГ МОДЕЛА}

\section{Будо Зиндовић, Љубодраг Савић, Радомир Капор, Никола Младеновић}

Тема рада је моделирање струјног поља на степенастом брзотоку бране Боговина. Анализа је спроведена на резултатима добијених помоћу: физичког модела, емпиријских једначина и нумеричког модела. Слагања резултата емпиријских једначина и нумеричког модела су у прихватљивим границама, док је примећено њихово значајно одступање од резултата мерења на физичком моделу. Узрок ових разлика је процес само-аерације млаза. Будући да је овај процес важан за овај вид струјања, непоходно је побољшати постојеће емпиријске зависности и нумеричке моделе. 